Supplement of Biogeosciences, 11, 4015-4028, 2014

http://www.biogeosciences.net/11/4015/2014/

doi:10.5194/bg-11-4015-2014-supplement

(C) Author(s) 2014. CC Attribution 3.0 License.

(c) (i)

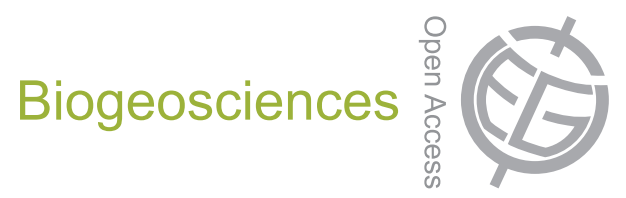

Supplement of

\title{
Greenland Ice Sheet exports labile organic carbon to the Arctic oceans
}

E. C. Lawson et al.

Correspondence to: E. C. Lawson (emily.lawson@nottingham.ac.uk) 


\section{Supplement}

\section{Section 1. Field sampling and monitoring}

\subsection{Field sampling}

Supraglacial and subglacial runoff samples were collected from the sampling sites (Table S1) in pre-furnaced $\left(400^{\circ} \mathrm{C}\right.$ for $6 \mathrm{hrs}$ ) borosilicate glass bottles and filtered $<2 \mathrm{hrs}$ after collection using either plastic apparatus with $0.45 \mu \mathrm{m}$ cellulose-nitrate membrane filters (major ion and dissolved Si determination) or pre-furnaced glass filtration apparatus with pre-furnaced GF/F $0.70 \mu \mathrm{m}$ filters (OC compound analysis). Cryoconite hole water samples were filtered in the field through Whatman polypropylene Puradisc ${ }^{\mathrm{TM}} 0.45 \mu \mathrm{m}$ syringe filters and stored frozen in pre-furnaced glass vials. Water samples were stored in the dark at $-12{ }^{\circ} \mathrm{C}$ (in-field freezer) prior to storage in the University of Bristol LOWTEX facility $\left(\leq-20^{\circ} \mathrm{C}\right)$. For snow and basal ice collection, the outermost layers (which are potentially subject to modern contamination) were first removed before sampling. Sediment-rich basal ice from the glacier terminus was collected by chain sawing, transported frozen and stored at $\leq-20{ }^{\circ} \mathrm{C}$ prior to analysis. Snow was collected by using a pre-furnaced metal trowel and stored at $\leq-20^{\circ} \mathrm{C}$ in pre-furnaced foil envelopes.

\subsection{Monitoring}

Water stage in the main subglacial outflow channel was logged at 5 minute intervals, at a stable bedrock section $\sim 2.2 \mathrm{~km}$ downstream from the glacier terminus (Figure 1) and converted to discharge $\left(\mathrm{Q}, \mathrm{m}^{3} \mathrm{~s}^{-1}\right)$ using a rating curve $(\mathrm{r}=0.92)$ with an uncertainty of \pm 15\% (as detailed in (Bartholomew et al., 2011; Cowton et al., 2012)). Suspended sediment concentration (SSC, $\mathrm{g} \mathrm{L}^{-1}$ ) was derived by calibrating turbidity measurements (logged every 5 
mins) against 80 manual grab samples taken throughout the two seasons $(r=0.92$ with an uncertainty of $\pm 6 \%$ ). Suspended sediment samples were filtered through $0.45 \mu \mathrm{m}$ filter papers, then dried and weighed in the laboratory, as described in (Cowton et al., 2012). 
Table S1 Location of the 2009-2011 sampling sites and sampling information.

\begin{tabular}{|c|c|c|c|c|c|c|}
\hline \multirow{3}{*}{$\begin{array}{l}\text { Year } \\
2009\end{array}$} & \multirow{3}{*}{$\begin{array}{c}\text { Sample details } \\
\text { Subglacial runoff }\end{array}$} & \multirow{3}{*}{$\begin{array}{c}\begin{array}{c}\text { Elevation } \\
\text { (a.s.l) }\end{array} \\
209 \mathrm{~m}\end{array}$} & \multicolumn{2}{|c|}{ Geographical Position } & \multirow{3}{*}{$\begin{array}{c}\text { Date sampled } \\
\text { June } 23 \text { - Aug } 18\end{array}$} & \multirow{3}{*}{$\begin{array}{c}\mathbf{n} \\
105\end{array}$} \\
\hline & & & \multirow{2}{*}{$67^{\circ} 06^{\prime} 23.50^{\prime \prime}$} & \multirow{2}{*}{$\frac{\mathbf{W}}{50^{\circ} 20^{\prime} 33.40^{\prime \prime}}$} & & \\
\hline & & & & & & \\
\hline & Moulin 2.1 km & $380 \mathrm{~m}$ & $67^{\circ} 03^{\prime} 58.20^{\prime \prime}$ & $50^{\circ} 08^{\prime} 23.00^{\prime \prime}$ & June $29-$ Aug 5 & 14 \\
\hline & Moulin 2.2 km & $343 \mathrm{~m}$ & $67^{\circ} 04^{\prime} 01.70^{\prime \prime}$ & $50^{\circ} 09^{\prime} 07.10^{\prime \prime}$ & June 29 - Aug 5 & 8 \\
\hline \multirow[t]{11}{*}{2010} & Subglacial runoff & $209 \mathrm{~m}$ & $67^{\circ} 06^{\prime} 23.50^{\prime \prime}$ & $50^{\circ} 20^{\prime} 33.40^{\prime \prime}$ & May $25-$ Aug 21 & 190 \\
\hline & Moulin 2.1 km & $380 \mathrm{~m}$ & $67^{\circ} 03^{\prime} 58.20^{\prime \prime}$ & $50^{\circ} 08^{\prime} 23.00^{\prime \prime}$ & June 4 - Aug 17 & 6 \\
\hline & Moulin 2.3 km & $383 \mathrm{~m}$ & $67^{\circ} 04^{\prime} 24.50^{\prime \prime}$ & $50^{\circ} 07^{\prime} 62.70^{\prime \prime}$ & June 4 - Aug 17 & 2 \\
\hline & Moulin 4 km & $259 \mathrm{~m}$ & $67^{\circ} 04^{\prime} 48.40^{\prime \prime}$ & $50^{\circ} 01^{\prime} 64.40^{\prime \prime}$ & June 4 - July 29 & 8 \\
\hline & Moulin 7 km & $579 \mathrm{~m}$ & $67^{\circ} 05^{\prime} 08.00^{\prime \prime}$ & $50^{\circ} 01^{\prime} 40.10^{\prime \prime}$ & June $9-$ Aug 7 & 5 \\
\hline & Moulin $17 \mathrm{~km}$ & $713 \mathrm{~m}$ & $67^{\circ} 06^{\prime} 37.00^{\prime \prime}$ & $52^{\circ} 02^{\prime} 30.20^{\prime \prime}$ & June 2 and 7 & 2 \\
\hline & Moulin $33 \mathrm{~km}$ & $1022 \mathrm{~m}$ & $67^{\circ} 06^{\prime} 56.70^{\prime \prime}$ & $49^{\circ} 24^{\prime} 00.52^{\prime \prime}$ & June 7 & 1 \\
\hline & Snow $33 \mathrm{~km}$ & $1022 \mathrm{~m}$ & $67^{\circ} 06^{\prime} 56.70^{\prime \prime}$ & $49^{\circ} 24^{\prime} 00.52^{\prime \prime}$ & June 7 & 2 \\
\hline & $\begin{array}{c}\text { Supraglacial lake } \\
50 \mathrm{~km}\end{array}$ & $1446 \mathrm{~m}$ & $67^{\circ} 07^{\prime} 34.40^{\prime \prime}$ & $49^{\circ} 00^{\prime} 36.00^{\prime \prime}$ & June 7 & 1 \\
\hline & Snow $50 \mathrm{~km}$ & $1446 \mathrm{~m}$ & $67^{\circ} 07^{\prime} 34.40^{\prime \prime}$ & $49^{\circ} 00^{\prime} 36.00^{\prime \prime}$ & June 7 & 2 \\
\hline & Snow $70 \mathrm{~km}$ & $1446 \mathrm{~m}$ & $67^{\circ} 09^{\prime} 10.80^{\prime \prime}$ & $44^{\circ} 22^{\prime} 14.60^{\prime \prime}$ & June 7 & 2 \\
\hline \multirow[t]{10}{*}{2011} & Cryo $2 \mathrm{~km} \mathrm{a}$ & $330 \mathrm{~m}$ & $67^{\circ} 03^{\prime} 99.70^{\prime \prime}$ & $50^{\circ} 09^{\prime} 30.20^{\prime \prime}$ & 21 June & 2 \\
\hline & Cryo $2 \mathrm{~km} \mathrm{~b}$ & $332 \mathrm{~m}$ & $67^{\circ} 03^{\prime} 98.10^{\prime \prime}$ & $50^{\circ} 09^{\prime} 33.60^{\prime \prime}$ & 21 June & 2 \\
\hline & Cryo $2 \mathrm{~km} \mathrm{c}$ & $334 \mathrm{~m}$ & $67^{\circ} 03^{\prime} 98.00^{\prime \prime}$ & $50^{\circ} 09^{\prime} 27.10^{\prime \prime}$ & 21 June & 2 \\
\hline & Cryo $2 \mathrm{~km} \mathrm{~d}$ & $328 \mathrm{~m}$ & $67^{\circ} 03^{\prime} 98.50^{\prime \prime}$ & $50^{\circ} 09^{\prime} 21.90^{\prime \prime}$ & 21 June & 1 \\
\hline & Cryo $2 \mathrm{~km} \mathrm{e}$ & $337 \mathrm{~m}$ & $67^{\circ} 03^{\prime} 98.90^{\prime \prime}$ & $50^{\circ} 09^{\prime} 19.10^{\prime \prime}$ & 21 June & 2 \\
\hline & Cryo $2 \mathrm{~km} \mathrm{f}$ & $343 \mathrm{~m}$ & $67^{\circ} 03^{\prime} 99.30^{\prime \prime}$ & $50^{\circ} 09^{\prime} 05.80^{\prime \prime}$ & 21 June & 2 \\
\hline & Cryo $2 \mathrm{~km} \mathrm{~g}$ & $342 \mathrm{~m}$ & $67^{\circ} 03^{\prime} 98.70^{\prime \prime}$ & $50^{\circ} 08^{\prime} 98.90^{\prime \prime}$ & 21 June & 2 \\
\hline & Cryo $2 \mathrm{~km} \mathrm{~h}$ & $358 \mathrm{~m}$ & $67^{\circ} 04^{\prime} 00.20^{\prime \prime}$ & $50^{\circ} 09^{\prime} 00.00^{\prime \prime}$ & 21 June & 2 \\
\hline & Cryo 2 km i & $348 \mathrm{~m}$ & $67^{\circ} 04^{\prime} 02.30^{\prime \prime}$ & $50^{\circ} 09^{\prime} 04.00^{\prime \prime}$ & 21 June & 2 \\
\hline & Cryo $2 \mathrm{~km} \mathrm{j}$ & $343 \mathrm{~m}$ & $67^{\circ} 04^{\prime} 03.50^{\prime \prime}$ & $50^{\circ} 09^{\prime} 06.60^{\prime \prime}$ & 21 June & 1 \\
\hline
\end{tabular}




\section{Section 2. Basal ice and snow preparation}

To prepare the basal ice for analytical study, small chunks were chipped from the main block using a flame sterilised chisel. The outer $\sim 10-30 \mathrm{~mm}$ of these chips were removed with deionized water (DI, Millipore, Bedford, MA, USA). Both ice chips and snow samples were melted in a pre-cleaned beaker inside a laminar flow cabinet (Telstar Mini-H) under ambient laboratory conditions. The melt was then filtered through Whatman polypropylene Puradisc $^{\mathrm{TM}} 0.45 \mu \mathrm{m}$ syringe filters. Samples were analysed following the protocols for glacial meltwater (see below).

\section{Section 3. Analytical protocols}

\subsection{POC}

Particulate organic carbon (POC) was calculated as the difference between total sediment carbon (TC) and sediment inorganic carbon (IC). TC and IC were measured on a EuroVector EA1108 Elemental Analyser (EuroVector, Milan, Italy) and modified Coulomat 702 Analyser (Strohlein Instruments, Kaarst, Germany), respectively. The precision of determinations was $<5 \%$ and limit of detection (LOD) c. $0.1 \mathrm{mg} \mathrm{g}^{-1}$ (or $0.01 \%$ ). The accuracy of TC $\left(E_{T C}\right)$ and IC $\left(E_{I C}\right)$ determinations were $3 \%$ and $4 \%$, respectively, and we assume that these errors are independent. The uncertainty in the POC determinations $\left(E_{P O C}\right)$ was calculated from the quadratic sum as follows:

$$
\begin{aligned}
E_{P O C} & =\sqrt{\left(E_{T C}^{2}+E_{I C}{ }^{2}\right)} \\
& =\sqrt{\left(3^{2}+4^{2}\right)} \\
& = \pm 5 \%
\end{aligned}
$$




\subsection{Particulate carbohydrates}

Carbohydrate concentrations in basal sediment were determined by an acid-extraction protocol to convert any polysaccharides and sugar derivatives to lower molecular weight components (Jensen et al., 2005; Stibal et al., 2010), and were subsequently quantified by ion chromatography. The extraction method is described in brief; $250 \mathrm{mg}$ of wet debris was added to an $8 \mathrm{ml}$ glass screw-cap serum vial, fitted with a Teflon cap liner. $5 \mathrm{ml}$ of $1 \mathrm{M} \mathrm{H}_{2} \mathrm{SO}_{4}$ was added and the vial sealed. Samples were hydrolysed at $110^{\circ} \mathrm{C}$ for 24 hours. After cooling, samples were shaken for 30 mins and centrifuged. The supernatant was then neutralised to $\mathrm{pH} 4-5$ by the addition of $1 \mathrm{M} \mathrm{NaOH}$, and stored in sterile polypropylene tubes at $-20^{\circ} \mathrm{C}$ until analysis. Each extraction procedure was conducted in triplicate. Potential monosaccharide losses may occur during hydrolysis and were not compensated for (Jensen et al., 2005). Generally, minor losses only occur for most common carbohydrates, except for ribose and fructose, which are destroyed entirely (Borch and Kirchmann, 1997). Results are presented in Table S2. The carbohydrate concentrations presented comprise mono- and disaccharides that were not destroyed by the hydrolysis procedure, plus the hydrolysis product of polysaccharides present in the subglacial sediment.

Table S2. Summary statistics for carbohydrates in Leverett Glacier suspended sediment

\begin{tabular}{|c|c|c|}
\hline Day of Year & $\begin{array}{l}\text { Carbohydrate concentration } \\
\left(\mu g g^{-1}\right)\end{array}$ & $\begin{array}{l}\text { \% carbohydrates } \\
\text { in } P O C\end{array}$ \\
\hline 175.33 & 123.12 & 13.38 \\
\hline 182.75 & 216.44 & 23.53 \\
\hline 185.75 & 154.35 & 16.78 \\
\hline 191.75 & 61.62 & 6.70 \\
\hline 198.33 & 19.14 & 2.08 \\
\hline 205.33 & 22.10 & 2.40 \\
\hline 214.33 & 93.12 & 10.12 \\
\hline 219.75 & 14.52 & 1.58 \\
\hline 220.75 & 34.39 & 3.74 \\
\hline 222.33 & 152.58 & 16.58 \\
\hline 224.75 & 23.77 & 2.58 \\
\hline
\end{tabular}




\subsection{DOC}

DOC, measured as non-purgeable organic carbon, was determined by high temperature combustion $\left(680^{\circ} \mathrm{C}\right)$ using a Shimadzu TOC-V $\mathrm{V}_{\mathrm{CSN}} / \mathrm{TNM}-1$ Analyzer equipped with a high sensitivity catalyst. Daily precision and accuracy were determined via repeat analysis of a DOC standard solution containing potassium hydrogen phthalate $\left(\mathrm{C}_{8} \mathrm{H}_{5} \mathrm{KO}_{4}\right)$ (Merck, DE). These were $< \pm 6 \%$. The LOD was $5 \mu \mathrm{M}$ C. The Shimadzu TOC-V $\mathrm{V}_{\mathrm{CSN}} / \mathrm{TNM}-1$ Analyzer was also used to determine DOC concentrations in samples from the bioavailability experiments which contained a 90:10 (freshwater: marine water) matrix. The high sensitivity catalyst is not designed specifically for seawater, yet the relatively low proportion of seawater in our sample matrix did not unduly affect the reliability of the DOC determinations. We ran a 90:10 (freshwater: marine water) standard after every 6 samples and used this data to determine the precision and accuracy, which were comparable $(< \pm 8$ and $\pm 9 \%$, respectively) to the daily precision and accuracy determined when running glacial samples $(< \pm 6 \%$, standard made up with DI).

\subsection{Free carbohydrates and amino acids}

Free carbohydrate and free amino acid determinations were performed by an ICS-3000 dualanalysis Reagent-Free Ion Chromatography system (Dionex, Sunnyvale, CA, USA). Using electrolytic eluent generation, nine carbohydrates (fucose, rhamnose, arabinose, galactose, glucose, xylose/mannose, fructose/sucrose, ribose and lactose) were separated isocratically at a flow rate of $0.35 \mathrm{~mL} \mathrm{~min}^{-1}$ on a CarboPac PA20 column $(3 \times 150 \mathrm{~mm})$, after passing through a CarboPac PA20 guard column $(3 \times 30 \mathrm{~mm})$. Xylose/mannose and fructose/sucrose were reported together due to co-elution. Precision for fucose, rhamnose, arabinose, glucose and xylose/mannose was generally $c . \pm 5 \%$, and $c . \pm 10 \%$ for galactose, fructose/sucrose, ribose and lactose. Accuracy of a certified external standard (Dionex, CA, USA) was $< \pm 7 \%$ for all 
analytes. The limit of quantification (LOQ) was determined, defined as the concentration of the lowest standard that could be significantly differentiated from the next highest (e.g. $\bar{x}_{1} \pm$ $\sigma_{1}$ is significantly different from $\bar{x}_{2} \pm \sigma_{2}$, where $\bar{x}$ is the mean and $\sigma$ the standard deviation). The LOQ for free carbohydrates ranged from 10-80 nM C. Free amino acids were determined for a subset of glacial samples (Table $\mathrm{S} 3, \mathrm{n}=44$ ) and separated via gradient anion exchange on an AminoPac PA10 column $(2 \times 250 \mathrm{~mm})$, after passing through an AminoPac PA10 guard column $(2 \times 50 \mathrm{~mm})$. Pulsed electrochemical detection with an Au electrode was employed. A gradient mix of $0.25 \mathrm{M} \mathrm{NaOH}, 1.0 \mathrm{M} \mathrm{Na}$-acetate (NaOAC) and DI was used to elute 14 free amino acids (lysine, alanine, threonine, glycine, valine, serine/proline, isoleucine, leucine, methionine, phenylalanine, cysteine, aspartic acid, glutamic acid and tyrosine) at a flow rate of $0.25 \mathrm{~mL} \mathrm{~min}^{-1}$. Serine and proline were reported together due to co-elution. Precision was typically $c . \pm 5 \%$ for lysine, alanine, threonine, glycine, valine, serine/proline, isoleucine, leucine, methionine, and cysteine, and $c . \pm 10 \%$ for phenylalanine, aspartic acid, glutamic acid and tyrosine. Accuracy was $< \pm 7 \%$ for all analytes (certified external standard, Fluka Analytical). The LOQ ranged from 10-60 nM C.

\subsection{Major ions and dissolved $\mathrm{Si}$}

Major anions $\left(\mathrm{Cl}^{-}, \mathrm{NO}^{3-}, \mathrm{SO}_{4}{ }^{2-}\right)$ and cations $\left(\mathrm{Na}^{+}, \mathrm{K}^{+}, \mathrm{Mg}^{2+}, \mathrm{Ca}^{2+}\right)$ were measured on a DX500 Ion Chromatography system (Dionex, Sunnyvale, CA, USA) and $\mathrm{HCO}_{3}{ }^{-}$calculated by charge deficit. Measurement precision and accuracy was $c . \pm 4 \%$ and $c . \pm 7 \%$, respectively, although this increased near the instrument detection limit (c. $0.5 \mu \mathrm{eq} \mathrm{L}^{-1}$ ). $\mathrm{SO}_{4}{ }^{2-}, \mathrm{K}^{+}, \mathrm{Na}^{+}$, $\mathrm{Mg}^{2+}$ and $\mathrm{Ca}^{2+}$ concentrations in basal ice and subglacial runoff samples were corrected for snowpack contributions (Wadham et al., 1998), and the residual crustal-derived component denoted with an asterisk (*). Dissolved Si was determined using a continuous segmented- 
flow Bran and Luebbe AutoAnalyser. Measurement precision and accuracy was $c . \pm 0.5 \%$ and $c . \pm 10 \%$, respectively, and the LOD was $0.74 \mu \mathrm{mol} \mathrm{L} \mathrm{L}^{-1}$.

\subsection{Spectrofluorescence}

Synchronous fluorescence spectra were determined on a HORIBA Jobin Yvon Fluorolog-3 spectrofluorometer. Scans were performed at $1 \mathrm{~nm}$ increments with a $0.1 \mathrm{~s}$ integration period, $10 \mathrm{~nm}$ bandwidth and $18 \mathrm{~nm}$ offset between excitation and emission monochromators. All scans were corrected for Raman and Rayleigh scattering, and inner-filter effects, following the approach of previous work using spectrofluorescence to analyse DOC compounds in glacial samples, e.g. (Barker et al., 2006). To correct for Ramen scatter, we ran a DI sample at the start of each day and subtracted this from the glacial sample. To correct for Rayleigh scatter, we used the Fluorolog-3 software, which also accounted for inner-filter effects. All spectra were normalized to the sample fluorescence peak spectral maximum (i.e. the maximum fluorescent intensity in all glacial samples) following the methods of (Barker et al., 2006). Fluorophore recognition was based on values reported in the literature (Coble, 1996; Ferrari and Mingazzini, 1995; Miano and Senesi, 1992; Yamashita and Tanoue, 2003).

\subsection{Bioavailability experiments}

The bioavailability of DOC (BDOC) in glacial runoff was determined as the difference in DOC at the start and end of laboratory incubations (22 day duration) (Fellman et al., 2008; Fellman et al., 2010). Glacial runoff from Leverett Glacier terminus (glacial) and the Watson River near Kangerlussuaq $\left(67.28^{\circ} \mathrm{N}, 50.41^{\circ} \mathrm{W}\right)$ (proglacial) were filtered through $0.3 \mu \mathrm{m}$ (pre-furnaced $450{ }^{\circ} \mathrm{C}$ for $4 \mathrm{hr}$ ) ADVANTECH GF-75 glass fibre filters to remove microorganisms. After filtration, $90 \mathrm{~mL}$ of the glacial filtrate was placed into pre-furnaced $125 \mathrm{~mL}$ glass serum vials and a $10 \mathrm{~mL}$ microbial inoculum was added. Microbial inocula 
consisted of near-coastal marine water collected in July $2012 \sim 1 \mathrm{~km}$ from the Nuuk coastline $\left(64^{\circ} 08^{\prime} \mathrm{N}, 51^{\circ} 47^{\prime} \mathrm{W}\right) \sim 0.5 \mathrm{~m}$ below the ocean surface. Microbial inocula were filtered through pre-furnaced glass fibre filters of nominal pore size $2.7 \mu \mathrm{m}$. 18 BDOC incubations were set up ( 9 containing glacial runoff and 9 containing proglacial runoff) and incubated at $1^{\circ} \mathrm{C}$ in the dark. In addition, 21 control incubations we set up ( 9 proglacial runoff, 9 glacial runoff, and 3 marine water), each containing $100 \mathrm{~mL}$ of the respective water sample. Sample water was extracted after 1, 2 and 22 days (hereafter referred to as T(time)1, T2 and T22). Three replicate BDOC incubations were sampled at each time point for both Greenland glacial and proglacial runoff types, and used in determinations of DOC and bacterial cell abundance. Three glacial and proglacial control incubations were also sampled at each time point. The three marine controls were sampled at $\mathrm{T} 1$ only. At each sampling point, $25 \mathrm{~mL}$ from all sampled incubations was re-filtered through $0.45 \mu \mathrm{m}$ PP syringe filters for DOC determination and $50 \mathrm{~mL}$ aliquots (not filtered) were fixed in glutaraldehyde to a final concentration of $2 \%$ for the enumeration of bacteria. $10 \mathrm{~mL}$ aliquot samples were stained with DAPI (4',6-diamidino-2-phenylindole, Sigma), filtered onto $0.2 \mu \mathrm{m}$ black polycarbonate filters and counted under epifluorescence microscopy at a magnification of x1000 under UV excitation. Twenty Whipple grids were counted on each preparation. DOC was determined following the methods described in Section 3.3.

\section{Section 4. Flux calculations and uncertainties}

\subsection{Seasonal flux calculations from Leverett Glacier}

\subsubsection{DOC and free carbohydrate fluxes}

Seasonal DOC and free carbohydrate (FCHO) fluxes from Leverett Glacier catchment were calculated from measured analyte concentrations and discharge (Q). Q monitoring in both 
years commenced with the onset of runoff in the main subglacial outflow channel from Leverett Glacier, with chemical sampling taking place for the majority of this period. DOC and FCHO fluxes from Leverett catchment were calculated separately for the main monitoring period when chemical samples were collected, and the start (37 days in 2009, 13 in 2010) and end of each season (17 days in 2009, 42 in 2010) when only Q data was available. Water fluxes in 2009 and 2010 were $1.98 \times 10^{9} \mathrm{~m}^{3}$ and $1.03 \times 10^{9} \mathrm{~m}^{3}$ respectively (Cowton et al., 2012), accounting for $90 \%$ and $84 \%$ of the total seasonal runoff, based upon melt season duration (Mernild et al., 2010). Flux calculations during the chemical monitoring period followed a linear interpolation approach. Fluxes were calculated between two sampling points ( $\mathrm{S} 1$ and $\mathrm{S} 2$ ) by multiplying the measured DOC/FCHO concentration at S1 by the cumulative Q recorded between S1 and S2. Instantaneous fluxes between successive DOC/FCHO sampling points were then summed to give a total for the chemical monitoring period. Consequentially, the analyte concentration during these time periods (typically 10-14 hours) was assumed to remain constant. Early and late season fluxes were calculated from the product of a DOC/FCHO discharge-weighted mean (DWM) determined from the first and last week of DOC/FCHO measurements, respectively, and the total runoff flux for each period. In 2009, Q was monitored from DY 137-246. Towards the end of monitoring Q was c. $40 \mathrm{~m}^{3} \mathrm{~s}^{-1}$ and declining rapidly. In 2010, Q remained high at the cessation of monitoring. A return visit to the catchment on 29 September found that the river had fallen to insignificant levels $\left(<5 \mathrm{~m}^{3} \mathrm{~s}^{-1}\right)$ (Cowton et al., 2012). The total water flux for this period was calculated assuming a linear decline and multiplied by the end of season 2010 DWM to generate the additional 2010 DOC/FCHO fluxes.

\subsubsection{Uncertainty in DOC and FCHO flux calculations}


There are several sources of uncertainty that contribute to the potential error in DOC $\left(E_{D O C_{f} f l u x}\right)$ and $\mathrm{FCHO}\left(E_{F C H O_{-} f l u x}\right)$ flux calculations; 1$)$ uncertainties in Q calculations $\left(E_{Q}\right)$, given as $\pm 15 \%$ (Bartholomew et al., 2011), and 2) uncertainty in DOC $\left(E_{D}\right)$ and FCHO $\left(E_{F}\right)$ determintions as associated with the analytical procedures ( $\pm 6 \%$ and $\pm 7 \%$, respectively). We assume that the error due to uncertainty in the discharge measurements and from the $\mathrm{DOC} / \mathrm{FCHO}$ determinations are independent and compute the $E_{D O C_{-} \text {flux }}$ and $E_{F C H O_{-} \text {flux }}$ from the quadratic sums as follows:

$$
\begin{array}{lll}
E_{D O C_{-} \text {flux }} & = & \sqrt{ }\left(E_{Q}{ }^{2}+E_{D}{ }^{2}\right) \\
& = & \sqrt{ }\left(15^{2}+6^{2}\right) \\
& = & \pm 16.15 \% \\
E_{F C H O \_f l u x} & = & \sqrt{ }\left(E_{Q}{ }^{2}+E_{F}^{2}\right) \\
& = & \sqrt{ }\left(15^{2}+7^{2}\right) \\
& = \pm 16.55 \%
\end{array}
$$

\subsubsection{SSC and POC fluxes}

The SSC fluxes from Leverett Glacier catchment (in grams) were derived from the product of the discharge weighted mean SSC $\left(\mathrm{g} \mathrm{L}^{-1}\right)$ measured in Leverett runoff in 2009 and 2010 and the seasonal Leverett runoff fluxes (L) for these years (Cowton et al., 2012). These SSC fluxes were then multiplied by the minimum, mean and maximum Leverett Glacier POC contents in each year $(0.040,0.092$ and $0.151 \%$ in 2009 , and $0.010,0.043$ and $0.113 \%$ in 2010, respectively) to generate minimum, mean and maximum POC fluxes from the catchment. An additional $10 \%$ ( $\pm 9 \%$ uncertainty) was added to the 2010 POC flux based on an extrapolation of the Q and SSC record following the cessation of monitoring in 2010 
which indicated that the total SSC flux may be $\sim 10 \%$ greater than observed (Cowton et al., 2012).

\subsubsection{Uncertainty in POC flux calculations}

There are several sources of uncertainty that contribute to the potential error in POC $\left(E_{P O C_{-} f l u x}\right)$ flux calculations; 1) determining SSC by turbidity, 2) the subtraction of TC and IC to generate POC, and 3) the low number of samples used for POC determination. The greatest uncertainty is likely to be due to the low number of samples. Export from Leverett Glacier has been shown to be highly heterogeneous over time. This may not be captured fully by mean POC determinations. For instance, the percentage variation between minimum and maximum POC fluxes in 2009 is $36 \%$, and $79 \%$ in 2010 . However, we are unable to account for this in our calculations and are restricted to calculating uncertainty introduced by SSC and POC determinations. However, we try to account for this error term and have given an envelope of fluxes for POC export from Leverett Glacier, based on minimum, mean and maximum POC concentration in the suspended sediment. We also stress that this as an approximation for POC fluxes.

The level of uncertainty in deriving $\operatorname{SSC}\left(E_{S S C}\right)$ by calibrating turbidity measurements with the 80 manual grab samples was $\pm 6 \%$. POC determinations had an uncertainty $\left(E_{P O C}\right)$ of \pm $5 \%$. We assume that these two errors terms are independent and compute the $E_{P O C_{-} \text {flux }}$ as follows:

$$
\begin{aligned}
E_{P O C_{-} \text {flux }} & =\sqrt{\left(E_{S S C}{ }^{2}+E_{P O C^{2}}\right)} \\
& =\sqrt{ }\left(6^{2}+5^{2}\right) \\
& = \pm 7.81 \%
\end{aligned}
$$


The 2010 POC fluxes have an additional source of uncertainty to account for associated with the additional SSC exported following the cessation of monitoring in 2010 (Section 4.1.3). This was calculated as $10 \pm 9 \%$ (Cowton et al., 2012). This increases the uncertainty of the $2010 E_{P O C_{-} \text {flux }}$ to \pm 11.92 .

\subsection{Annual flux calculations from the Greenland Ice Sheet}

Annual DOC and free carbohydrate fluxes from the Greenland Ice Sheet (GrIS) were calculated from the product of the annual GrIS runoff $\left(347.9 \mathrm{~km}^{3} \mathrm{yr}^{-1}\right.$ in 2009 and $558.9 \mathrm{~km}^{3}$ $\mathrm{yr}^{-1}$ in 2010) (Fettweis et al., 2011) and seasonal discharge weighted mean (DWM) DOC and free carbohydrate concentrations from Leverett Glacier. We calculated an envelope of POC fluxes from the GrIS. Briefly, the GrIS SSC flux in 2009 and 2010 (in grams) was derived from the product of the discharge weighted mean $\operatorname{SSC}\left(\mathrm{g} \mathrm{L}^{-1}\right)$ measured in Leverett runoff in 2009 and 2010 and the seasonal GrIS runoff fluxes (L) for these years. These SSC fluxes were then multiplied by the minimum, mean and maximum Leverett Glacier POC contents in each year $(\%)$ to generate minimum, mean and maximum POC fluxes from the ice sheet.

\subsubsection{Uncertainty in DOC flux calculations}

There are several sources of uncertainty that contribute to the potential error in GrIS DOC $\left(E_{\text {GrIS_DOC_flux }}\right)$ and GrIS FCHO $\left(E_{\text {GrIS_FCHO_flux }}\right)$ flux calculations; 1) uncertainties in Q calculations $\left(E_{G r I S_{-} Q}\right)$, on average, $12 \%$ (X. Fettweis, pers. comm), and 2) uncertainty in DOC $\left(E_{D}\right)$ and $\mathrm{FCHO}\left(E_{F}\right)$ as determined by analytical procedures $( \pm 6 \%$ and $\pm 7 \%$, respectively).

We assume that the error terms are independent and compute the $E_{G r I S_{-} D O C_{-} f l u x}$ and $E_{\text {GrIS_FCHO_flux }}$ as follows:

$$
\begin{aligned}
E_{G r I S_{-} D O C_{\_} f l u x} & =\sqrt{ }\left(E_{G r I S_{-} Q}{ }^{2}+E_{D}{ }^{2}\right) \\
& =\sqrt{ }\left(12^{2}+6^{2}\right)
\end{aligned}
$$




$$
\begin{aligned}
& =\quad \pm 13.42 \%
\end{aligned}
$$

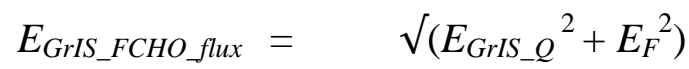

$$
\begin{aligned}
& =\sqrt{\left(12^{2}+7^{2}\right)} \\
& =\quad \pm 13.89 \%
\end{aligned}
$$

\subsubsection{Uncertainty in POC flux calculations}

There are several sources of uncertainty that contribute to the potential error in GrIS POC $\left(E_{G r I S_{-} P O C_{f} f l u x}\right)$ flux calculations; 1$)$ uncertainties in the SSC $\left(E_{S S C}\right)$ determinations $\left.( \pm 6 \%), 2\right)$ uncertainties in Q calculations $\left(E_{G r I S \_}\right)$, on average, $12 \%$, and 3) uncertainty in the POC $\left(E_{P O C}\right)$ determinations based on analytical accuracy $( \pm 5 \%)$. We assume that these three errors terms are independent and compute the $E_{G r I S_{-} P O C_{-} f l u x}$ as follows:

$$
\begin{aligned}
& \left.E_{G r I S_{-} P O C_{-} \text {flux }}=\sqrt{(} E_{S S C}{ }^{2}+E_{G r I S_{-} Q}{ }^{2}+E_{P O C}{ }^{2}\right) \\
& =\sqrt{\left(6^{2}+12^{2}+5^{2}\right)} \\
& =\quad \pm 14.32 \%
\end{aligned}
$$

\section{Section 5. Supplementary data}

We present free amino acid concentrations for a subset of glacial samples (Table S3, n = 44), and major inorganic and organic compound concentrations in subglacial runoff from 2009 (Table S4) and 2010 (Table S5). 
Table S3 Free amino acid concentrations in a subset of subglacial and supraglacial samples collected in 2010-11.

\begin{tabular}{cccccc}
\hline Sample & $\begin{array}{c}\text { Mean free amino } \\
\text { acids }(\boldsymbol{\mu M} \mathbf{C})\end{array}$ & $\begin{array}{c}\text { Free amino acid } \\
\text { range }(\boldsymbol{\mu M ~ C})\end{array}$ & $\mathbf{n}$ & $\begin{array}{c}\text { \% free amino } \\
\text { acids in DOC }\end{array}$ & $\begin{array}{c}\text { \% free amino acids } \\
\text { in DOC range }\end{array}$ \\
\hline $\begin{array}{c}\text { Subglacial } \\
\text { runoff 2010 }\end{array}$ & $1.06(1.08)$ & $0.03-4.22$ & 20 & $1.24(1.23)$ & $0.02-4.23$ \\
$\begin{array}{c}\text { Supraglacial } \\
(\mathbf{2 - 7} \mathbf{~ k m})\end{array}$ & $0.23(0.41)$ & $0.00-0.84$ & 4 & $1.02(1.64)$ & $0.00-3.44$ \\
$\quad$ Snow & $0.59(0.02)$ & $0.57-0.60$ & 2 & $1.93(0.13)$ & $1.83-2.02$ \\
Basal ice & $0.11(0.14)$ & $0.01-0.44$ & 10 & $0.29(0.40)$ & $0.01-1.31$ \\
$\begin{array}{c}\text { Cryoconite } \\
\text { waters }(\mathbf{2} \mathbf{~ k m})\end{array}$ & $5.85(6.09)$ & $0.27-16.77$ & 8 & $2.09(1.08)$ & $0.08-3.08$ \\
\hline
\end{tabular}


Table S4 Major inorganic and organic compound concentrations measured in time periods from the 2009 melt season. The melt season was subdivided on the basis of contrasting geochemistry into early season runoff (E2009), runoff predominantly exported before and after DY 194 (RS1 and RS2, respectively, RS = res of season), and the P-event, P1(2009). Values reported are the mean concentrations with standard deviation (SD) in parentheses. The range of concentrations is given in italics. Outliers of individual analytes exceeding the mean $\pm 3 \mathrm{x}$ SD have been excluded. Ionic strength refers to snowpack corrected concentrations. n.d. = not determined.

\begin{tabular}{|c|c|c|c|c|c|c|c|}
\hline Time period & $\overline{D O C}(\mu \mathrm{M} \mathrm{C})$ & FCHO (nM C) & $\begin{array}{l}\text { \% DOC from } \\
\text { FCHO }\end{array}$ & $\underset{(\mu \mathrm{mol} \mathrm{L}}{\mathbf{S i})}$ & $\begin{array}{c}* \mathrm{SO}_{4}^{2-} \\
\left(\mu \mathrm{eq} \mathbf{L}^{-1}\right)\end{array}$ & $\begin{array}{c}{ }^{*} \mathbf{N a}^{+}+{ }^{*} \mathbf{K}^{+} \\
\left(\mu \mathrm{eq} \mathbf{L}^{-1}\right)\end{array}$ & $\begin{array}{c}\text { Ionic strength } \\
\left(\mu \mathrm{eq} \mathbf{L}^{-1}\right)\end{array}$ \\
\hline $\begin{array}{c}\text { E2009 } \\
\text { (DY 174-179) }\end{array}$ & $\begin{array}{c}62.70(26.46) \\
27.92-104.60\end{array}$ & $\begin{array}{c}89.23(59.58) \\
38.36-255.71\end{array}$ & $\begin{array}{l}0.17(0.12) \\
0.06-0.38\end{array}$ & $\begin{array}{l}6.64(1.24) \\
5.12-9.30\end{array}$ & $\begin{array}{c}34.66(6.89) \\
25.07-42.79\end{array}$ & $\begin{array}{l}62.19(10.78) \\
45.65-80.12\end{array}$ & $\begin{array}{c}345.87(46.47) \\
286.26-412.59\end{array}$ \\
\hline $\begin{array}{c}\text { P1(2009) } \\
\text { (DY 184-186) }\end{array}$ & $\begin{array}{l}42.14(17.56) \\
26.92-66.91\end{array}$ & $\begin{array}{l}346.24(431.07) \\
113.97-1223.67\end{array}$ & $\begin{array}{l}0.71(0.56) \\
0.29-1.83\end{array}$ & $\begin{array}{c}8.23(1.40) \\
6.86-10.82\end{array}$ & $\begin{array}{c}63.33(7.80) \\
51.63-70.38\end{array}$ & $\begin{array}{l}132.37(21.72) \\
99.30-156.38\end{array}$ & $\begin{array}{c}559.33(56.84) \\
466.96-618.28\end{array}$ \\
\hline $\begin{array}{c}\text { RS1 } \\
\text { (DY 180-193) }^{\S}\end{array}$ & $\begin{array}{c}38.67(23.76) \\
12.25-124.15\end{array}$ & $\begin{array}{c}133.45(141.56) \\
2.11-521.83\end{array}$ & $\begin{array}{l}0.27(0.29) \\
0.00-0.98\end{array}$ & $\begin{array}{l}6.15(1.15) \\
4.51-8.89\end{array}$ & $\begin{array}{l}24.39(7.45) \\
7.83-44.21\end{array}$ & $\begin{array}{l}52.64(17.64) \\
14.03-91.29\end{array}$ & $\begin{array}{c}289.64(59.80) \\
133.05-414.22\end{array}$ \\
\hline $\begin{array}{c}\text { RS2 } \\
\text { (DY 194-230) }\end{array}$ & $\begin{array}{c}39.68(22.63) \\
12.40-106.87\end{array}$ & $\begin{array}{c}98.54(133.87) \\
1.50-682.95\end{array}$ & $\begin{array}{c}0.16(0.19) \\
0.00-0.85)\end{array}$ & $\begin{array}{l}7.17(0.79) \\
5.72-8.98\end{array}$ & $\begin{array}{c}29.96(4.31) \\
22.17-38.37\end{array}$ & $\begin{array}{c}32.88(2.71) \\
25.55-37.89\end{array}$ & $\begin{array}{c}223.10(27.10) \\
158.66-268.73\end{array}$ \\
\hline Seasonal average & $\begin{array}{c}41.35(23.19) \\
12.25-124.15\end{array}$ & $\begin{array}{c}120.65(171.67) \\
1.50-1223.67\end{array}$ & $\begin{array}{l}0.22(0.27) \\
0.00-1.83\end{array}$ & $\begin{array}{c}6.92(1.10) \\
4.51-10.82\end{array}$ & $\begin{array}{c}31.22(10.36) \\
7.83-70.37\end{array}$ & $\begin{array}{c}47.08(26.51) \\
14.03-156.38\end{array}$ & $\begin{array}{c}274.11 \\
133.05-618.67)\end{array}$ \\
\hline
\end{tabular}


Table S5 Major inorganic and organic compound concentrations measured in time periods from the 2010 melt season. The melt season was subdivided on the basis of contrasting geochemistry into early season runoff (E2010) and three P-events. RS accounts for the remainder of the drainage season not characterised by specific periods. Values reported are the mean concentrations with standard deviation (SD) in parentheses. The range of concentrations is given in italics. Outliers of individual analytes exceeding the mean $\pm 3 \times$ SD have been excluded. Ionic strength refers to snowpack corrected concentrations. n.d. $=$ not determined.

\begin{tabular}{|c|c|c|c|c|c|c|c|}
\hline Time period & DOC $(\mu M C)$ & FCHO (nM C) & $\begin{array}{l}\text { \% DOC from } \\
\text { FCHO }\end{array}$ & $\begin{array}{c}\mathrm{Si} \\
(\mu \mathrm{mol} \mathrm{L} \\
\left.\mathbf{L}^{-1}\right)\end{array}$ & $\begin{array}{c}{ }^{*} \mathrm{SO}_{4}{ }^{2-} \\
\left(\mu \mathrm{eq} \mathbf{L}^{-1}\right)\end{array}$ & $\begin{array}{c}{ }^{*} \mathrm{Na}^{+}+{ }^{*} \mathrm{~K}^{+} \\
\left(\mu \mathrm{eq} \mathbf{L}^{-1}\right)\end{array}$ & $\begin{array}{c}\text { Ionic strength } \\
\left(\mu \mathrm{eq} \mathbf{L}^{-1}\right)\end{array}$ \\
\hline $\begin{array}{c}\text { E2010 } \\
\text { (DY 150-155) }\end{array}$ & $\begin{array}{l}19.66(8.99) \\
9.34-38.20\end{array}$ & $\begin{array}{l}88.68(92.52) \\
3.86-704.03\end{array}$ & $\begin{array}{l}0.42(0.28) \\
0.07-0.92\end{array}$ & $\begin{array}{l}5.11(2.06) \\
2.18-8.12\end{array}$ & $\begin{array}{c}36.46(7.95) \\
23.80-48.57\end{array}$ & $\begin{array}{c}70.12(9.64) \\
48.68-81.82\end{array}$ & $\begin{array}{l}354.92(9.64) \\
48.68-81.82\end{array}$ \\
\hline $\begin{array}{c}\text { P1(2010) } \\
\text { (DY 160-164) }\end{array}$ & $\begin{array}{l}16.04(9.30) \\
8.28-31.96\end{array}$ & $\begin{array}{l}30.02(15.90) \\
11.24-55.70\end{array}$ & $\begin{array}{l}0.21(0.10) \\
0.12-0.38\end{array}$ & $\begin{array}{l}3.26(0.57) \\
2.82-4.57\end{array}$ & $\begin{array}{c}35.30(5.74) \\
29.32-45.37\end{array}$ & $\begin{array}{c}62.08(7.54) \\
49.27-71.48\end{array}$ & $\begin{array}{c}325.96(21.15) \\
294.29-356.12\end{array}$ \\
\hline $\begin{array}{c}\text { P2(2010) } \\
\text { (DY 166-169) }\end{array}$ & $\begin{array}{l}12.08(4.63) \\
6.47-20.73\end{array}$ & $\begin{array}{l}24.88(18.67) \\
14.86-65.81\end{array}$ & $\begin{array}{l}0.17(0.11) \\
0.00-0.32\end{array}$ & $\begin{array}{l}4.39(1.73) \\
2.08-7.00\end{array}$ & $\begin{array}{c}30.73(7.19) \\
16.67-43.53\end{array}$ & $\begin{array}{c}49.07(9.95) \\
32.88-60.85\end{array}$ & $\begin{array}{c}276.35(42.60) \\
191.26-326.16\end{array}$ \\
\hline $\begin{array}{c}\text { P3(2010) } \\
\text { (DY 181-184) }\end{array}$ & $\begin{array}{c}20.32(5.58) \\
10.75-29.92\end{array}$ & $\begin{array}{l}58.23(44.76) \\
6.76-176.55\end{array}$ & $\begin{array}{l}0.28(0.19) \\
0.02-0.68\end{array}$ & $\begin{array}{l}3.22(1.25) \\
1.45-5.86\end{array}$ & $\begin{array}{l}49.59(21.07) \\
16.69-79.20\end{array}$ & $\begin{array}{c}70.85(30.58) \\
18.63-106.85\end{array}$ & $\begin{array}{c}357.38(83.90) \\
194.20-467.12\end{array}$ \\
\hline $\mathbf{R S}$ & $\begin{array}{l}17.82(10.97) \\
5.16-70.25\end{array}$ & $\begin{array}{c}86.88(105.23) \\
3.86-704.03\end{array}$ & $\begin{array}{l}0.63(1.21) \\
0.00-9.90\end{array}$ & $\begin{array}{l}3.22(1.08) \\
1.29-5.56\end{array}$ & $\begin{array}{c}29.99(12.63) \\
5.97-64.60\end{array}$ & $\begin{array}{l}47.23(19.16) \\
7.78-102.78\end{array}$ & $\begin{array}{l}244.17(68.73) \\
63.15-408.22\end{array}$ \\
\hline Seasonal average & $\begin{array}{c}17.66(10.17) \\
5.16-70.25\end{array}$ & $\begin{array}{l}77.24(93.57) \\
3.86-704.03\end{array}$ & $\begin{array}{l}0.52(1.01) \\
0.00-9.90\end{array}$ & $\begin{array}{l}3.43(1.31) \\
1.29-8.12\end{array}$ & $\begin{array}{c}32.72(14.06) \\
5.97-79.20\end{array}$ & $\begin{array}{l}52.15(21.06) \\
7.78-106.85\end{array}$ & $\begin{array}{l}269.58(78.48) \\
63.15-467.12\end{array}$ \\
\hline
\end{tabular}




\section{Section 6. Statistical analysis}

A cross tabulation analysis was undertaken using SPSS 17.0 statistical software to assess the degree of synchronicity between DOC and FCHO spikes in the subglacial runoff. Data were first recoded into categorical variables (peak and no-peak, denoted as 1 and 0 , respectively) where values within the top $10^{\text {th }}$ percentile of each dataset were designated as peaks and missing values excluded from the analyses. Separate tests were conducted for the 2009 and 2010 datasets. Data were put into chronological order and the DOC_Peak_No_Peak column compared with the FCHO_Peak_No_Peak using asymptotic tests and employing an exact method (i.e. no Monte Carlo testing). Observed counts were used and the non-integer weights were rounded to whole numbers. In both years $\sim 30 \%$ of all DOC and free carbohydrate peaks were synchronous. Attribute agreement analysis (Kappa statistics, 95\% significance level) were used to determine the association between the timing of the DOC and FCHO spikes (Tables S6-S7). A Kappa value of 0 suggests that the agreement is the same as would be expected by chance, a value of 1 indicates perfect agreement and a value $<1$ suggests that the agreement is less than that expected by change. Kappa values of 0.228 and 0.236 (2009 and 2010) are above that which would be expected by chance but do not indicate significant agreement between DOC and FCHO peaks. From this we conclude that DOC and FCHO spikes are predominantly asynchronous.

Further cross tabulation analyses were undertaken to assess the degree of synchronicity between all measured geochemical, organic and physical parameters e.g. DOC vs. discharge, discharge vs. major ions, DOC, free carbohydrates and $\mathrm{Si}$, to help resolve questions regarding the mobilization of discrete subglacial OC pools and reconcile source contribution to the net OC flux. We report no significant association between the timing of the peaks of the 
measured geochemical, organic and physical parameters, and find predominant asynchronicity (data not shown). This supports the previous assertions that runoff exported from GrIS outlet glaciers has multiple sources that supply bulk runoff to varying degrees throughout the melt season.

Table S6 Cross-tabulation of DOC and FCHO peaks (defined by the upper $10^{\text {th }}$ percentile) in subglacial runoff from 2009. Values equal the number of cases.

\begin{tabular}{lcccc}
\hline 2009 & FCHO Peak & FCHO No_Peak & Total & Kappa \\
& & & & \\
\hline DOC Peak & 3 & 7 & 10 & \\
DOC No_Peak & 6 & 67 & 73 & \\
Total & 9 & 74 & 83 & 0.228 \\
\hline
\end{tabular}

Table S7 Cross-tabulation of DOC and FCHO peaks (defined by the upper $10^{\text {th }}$ percentile) in subglacial runoff from 2010. Values equal the number of cases.

\begin{tabular}{lcccc}
\hline 2010 & FCHO Peak & FCHO No_Peak & Total & Kappa \\
\hline DOC Peak & 5 & 11 & 16 & \\
DOC No_Peak & 11 & 132 & 143 & \\
Total & 16 & 143 & 159 & 0.236 \\
\hline
\end{tabular}

\section{Section 7. Delineation of snowline migration at Leverett Glacier}

An approximation of the Leverett Glacier hydrological catchment was first derived from a surface digital elevation model (Bartholomew et al., 2011; Palmer et al., 2011). Cloud-free satellite images (1 image per day) from the Moderate-resolution Imaging Spectrometer (MODIS) (Ardanuy et al., 1991) from $10^{\text {th }}$ May to $18^{\text {th }}$ August (DY 130-230) 2009 and 2010 were then imported into ArcGIS software and used to track snowline retreat over the Leverett Glacier catchment (Figure S1). Snowline position was identified by visual inspection and designated as the boundary between the grey/pale-blue surface (interpreted as snow-free 
glacier ice) and brilliant white surface (interpreted as snow). The presence of ice-free supraglacial lakes confirmed that areas were snow-free. The daily maximum and minimum snowline extent was determined by measuring the nearest and furthest distances of the snowline, using a straight line due east from the Leverett Glacier margin. Early in the melt season when the catchment was predominantly snow-covered, the snowline was defined at the glacier margin positions (outer edge of the catchment area). When the snowline retreated beyond the catchment area later in the season, the nearest and furthest points were measured at the northerly and southerly bounds of the catchment area $\left(\sim 66.72--67.17{ }^{\circ} \mathrm{N}\right)$. The difference between maximum and minimum snowline extent, and hence uncertainty, was $~ 5$ $10 \mathrm{~km}$. The MODIS data used in this study were acquired using the NASA/GSFC, Rapid Response Imagery as part of the Land Atmosphere Near-real time Capability for EOS (LANCE) system operated by the NASA/GSFC/Earth Science Data and Information System (ESDIS) with funding provided by NASA/HQ. Images were available from

http://rapidfire.sci.gsfc.nasa.gov/subsets/?project=aeronet\&subset=Kangerlussuaq.yyyyddd.te rra. $250 \mathrm{~m}$, where yyyy is the year and $d d d$ the day. 
Figure S1 Distance from the GrIS margin to the estimated snow line in the Leverett Glacier catchment and migration over the course of the 2009 (blue) and 2010 (red) melt seasons. The two lines for each year refer to the minimum and maximum snowline estimated snowline extent.

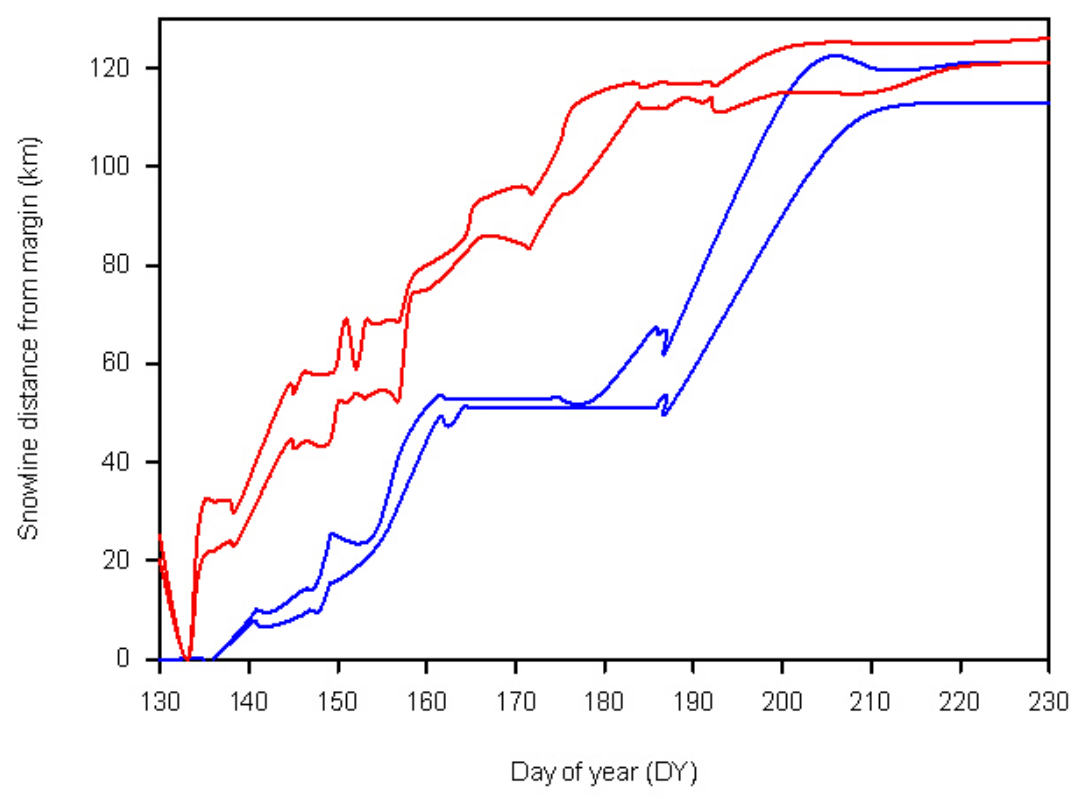




\section{Section 8. Leverett Glacier as a representative of Greenland land-terminating glaciers}

Leverett Glacier catchment has a size $\left(>600 \mathrm{~km}^{2}\right)$ and altitudinal range (100 to $>1000 \mathrm{~m}$ a.s.l) representative of many Greenland land-terminating glaciers (Bartholomew et al., 2011). With relevance to subglacial organic carbon cycling processes, we note that the debris composition and sediment morphology beneath Leverett Glacier is representative of $\sim 77 \%$ of the West Greenland ice margin (Knight et al., 2002). In addition, the bedrock geology (Archaean gneiss reworked in the Proterozoic) at Leverett catchment is representative of the crystalline bedrock that dominates Greenland (Henriksen et al., 2000). Surface-derived DOC acquisition is thought to be controlled by microbial processes on the ice sheet surface, which are also ubiquitous across glacial systems within surface melt features (e.g. melting ice/snow, cryoconite holes, lakes) (Hodson et al., 2010; Telling et al., 2012). Hence, we have no reason to believe that surface organic carbon cycling and export at Leverett Glacier would be substantially different to any other melting glacial ice surface in Greenland. We acknowledge that there are climatological differences between north and south Greenland (e.g. driven by air temperature), which may affect rates of melting, but which should not affect pathways of microbial carbon cycling on glacier surfaces. Glacial runoff dynamics at Leverett Glacier, which drive OC export at the margin, are believed to characterise those across the GrIS western margin, demonstrating progressive upglacier seasonal expansion and evolution of both supraglacial and subglacial drainage systems (Bartholomew et al., 2011; Sundal et al., 2011). This suggests that the drivers for OC export at Leverett Glacier are widely applicable. While the fate of this runoff may differ between land-terminating glaciers such as Leverett Glacier and marine-terminating glaciers, this should not affect the export dynamics for OC at the ice margin. Hence, while we acknowledge that inter-site differences will always be apparent within very large glacial systems, our GrIS flux estimates derived from scaling up of 
Leverett Glacier OC fluxes should provide robust order of magnitude estimates of fluxes from the GrIS. 


\section{Supplementary References}

Ardanuy, P.E., Han, D., Salomonson, V.V., 1991. The moderate resolution imaging spectrometer (MODIS) science and data system requirements. Geoscience and Remote Sensing, IEEE Transactions on $29,75-88$.

Barker, J.D., Sharp, M.J., Fitzsimons, S.J., Turner, R.J.: Abundance and dynamics of dissolved organic carbon in glacier systems. Arctic Antarctic and Alpine Research 38, 163-172, 2006.

Bartholomew, I., Nienow, P., Sole, A., Mair, D., Cowton, T., Palmer, S., Wadham, J., 2011. Supraglacial forcing of subglacial drainage in the ablation zone of the Greenland ice sheet. Geophysical Research Letters 38, L08502.

Borch, N.H., Kirchmann, D.L., 1997. Concentration and composition of dissolved combined neutral sugars (polysaccharides) in seawater determined by HPLC-PAD. Marine Chemistry 57, 85-95.

Coble, P.G., 1996. Characterization of marine and terrestrial DOM in seawater using excitation emission matrix spectroscopy. Marine Chemistry 51, 325-346.

Cowton, T., Nienow, P., Bartholomew, I., Sole, A., Mair, D., 2012. Rapid erosion beneath the Greenland ice sheet. Geology 40, 343-346.

Fellman, J., D'Amore, D., Hood, E., Boone, R., 2008. Fluorescence characteristics and biodegradability of dissolved organic matter in forest and wetland soils from coastal temperate watersheds in southeast Alaska. Biogeochemistry 88, 169-184.

Fellman, J.B., Spencer, R.G.M., Hernes, P.J., Edwards, R.T., D'Amore, D.V., Hood, E., 2010. The impact of glacier runoff on the biodegradability and biochemical composition of terrigenous dissolved organic matter in near-shore marine ecosystems. Marine Chemistry 121, 112-122.

Ferrari, G.M., Mingazzini, M., 1995. Synchronous Fluorescence-Spectra of Dissolved Organic-Matter (Dom) of Algal Origin in Marine Coastal Waters. Marine Ecology-Progress Series 125, 305-315.

Henriksen, N., Higgins, A., Kalsbeek, F., Pulvertaft, T.C.R., 2000. Greenland from Archaean to Quaternary. Geological Survey of Denmark and Greenland.

Hodson, A., Boggild, C., Hanna, E., Huybrechts, P., Langford, H., Cameron, K., Houldsworth, A., 2010. The cryoconite ecosystem on the Greenland ice sheet. Annals of Glaciology 51, 123-129.

Jensen, M., Holmer, M., Thamdrup, B., 2005. Composition and diagenesis of neutral carbohydrates in sediments of the Baltic-North Sea transition. Geochimica Et Cosmochimica Acta 69, 4085-4099.

Knight, P., Waller, R., Patterson, C., Jones, A., Robinson, Z., 2002. Discharge of debris from ice at the margin of the Greenland ice sheet. Journal of Glaciology 48, 192-198.

Mernild, S.H., Liston, G.E., Steffen, K., van den Broeke, M., Hasholt, B., 2010. Increasing runoff from the Greenland Ice Sheet at Kangerlussuaq (Søndre Strømfjord) in a 30-year perspective, 1979\&ndash;2008. The Cryosphere Discuss. 4, 321-345.

Miano, T.M., Senesi, N., 1992. Synchronous Excitation Fluorescence Spectroscopy Applied to Soil Humic Substances Chemistry. Science of the Total Environment 118, 41-51.

Palmer, S., Shepherd, A., Nienow, P., Joughin, I., 2011. Seasonal speedup of the Greenland Ice Sheet linked to routing of surface water. Earth and Planetary Science Letters. 
Stibal, M., Lawson, E., Lis, G., Mak, K., Wadham, J., Anesio, A., 2010. Organic matter content and quality in supraglacial debris across the ablation zone of the Greenland ice sheet. Annals of Glaciology 51, 1-8.

Sundal, A.V., Shepherd, A., Nienow, P., Hanna, E., Palmer, S., Huybrechts, P., 2011. Melt-induced speed-up of Greenland ice sheet offset by efficient subglacial drainage. Nature 469, 521-524.

Telling, J., Stibal, M., Anesio, A., Tranter, M., Nias, I., Cook, J., Bellas, C., Lis, G., Wadham, J., Sole, A., 2012. Microbial nitrogen cycling on the Greenland Ice Sheet. Biogeosciences 9, 2431-2442.

Wadham, J.L., Hodson, A.J., Tranter, M., Dowdeswell, J.A., 1998. The hydrochemistry of meltwaters draining a polythermal-based, high Arctic glacier, south Svalbard: I. The ablation season. Hydrological Processes 12, 1825-1849.

Yamashita, Y., Tanoue, E., 2003. Chemical characterization of protein-like fluorophores in DOM in relation to aromatic amino acids. Marine Chemistry 82, 255-271. 